\title{
APAKAH KINERJA REKSADANA SAHAM SYARIAH LEBIH BAIK DIBANDINGKAN DENGAN REKSADANA SAHAM KONVENSIONAL?
}

\author{
${ }^{1}$ Dwi Fatmawati, ${ }^{2}$ Noor Faizah
}

\begin{abstract}
Abstrak
Penelitian ini membahas mengenai pengukuran kinerja antara reksadana saham konvensional dan reksadana saham syariah, dimana secara fundamental keduanya memiliki perbedaan. Tujuan dari penelitian ini adalah untuk memberikan informasi kepada calon investor manakah kinerja yang lebih baik antara reksadana saham konvensional dengan reksadana saham syariah. Jenis penelitian ini adalah deskriptif kuantitatif. Fokus penelitian ini dibatasi kedalam 3 objek penelitian yaitu metode Sharpe, Treynor, dan Jensen. Pengambilan sampel menggunakan metode purposive sampling. Populasi yang digunakan adalah sebanyak 208 reksadana saham konvensional dan 66 reksadana saham syariah. Sampel penelitian yang digunakan 7 reksadana saham konvensional dan 7 reksadana saham syariah. Sumber data dalam penelitian ini menggunakan data sekunder. Hasil penelitian ini mendapatkan bahwa reksadana saham konvensional lebih konsisten unggul daripada reksadana saham syariah.
\end{abstract}

Kata Kunci: kinerja, reksadana saham syariah, reksadana saham konvensional.

\section{Abstract}

Research on discussing the performance between conventional stock mutual funds and Islamic stock mutual funds, where fundamental fundamentals have differences. The purpose of this study is to provide information to prospective investors about better research results between conventional stock mutual funds and Islamic stock mutual funds. This type of research is quantitative descriptive. The focus of this study discusses three research methods, namely the Sharpe, Treynor, and Jensen methods. Sampling is used using the purposive sampling method. The population used was 208 mutual funds. And 66 mutual funds. The research sample used 7 conventional mutual funds and 7 Islamic stock mutual funds. Sources of data in this study using secondary data. The results of this study get conventional stock mutual funds superior Islamic stock mutual funds

Keywords: performance, sharia stock mutual funds, conventional stock mutual funds. 


\section{PENDAHULUAN}

Masyarakat Indonesia yang mayoritas beragama Islam patut bergembira dengan bangkitnya ekonomi Islam saat ini, hingga akhirmya produk pasar modal yang berbasis syariah pun kian meningkat tajam. Direktur Otoritas Jasa Keuangan (OJK) Fadilah Kartikasari memaparkan bahwa kapitalisasi pasar modal syariah sudah mencapai $53,18 \%$ dari total seluruh perusahaan yang sudah tercatat di Bursa Efek Indonesia (BEI). Adapun nilai kapitalisasinya mencapai Rp 3.778 triliun per 8 November 2019. Tercatat sebanyak 415 merupakan saham syariah dari total jumlah emiten BEI yang mencapai 659. Investasi pada financial assets menjadi sebuah cara yang banyak diminati oleh para pemilik modal untuk mengembangkan dana yang mereka miliki. Sehingga, selain masyarakat semakin paham dengan pengelolaan keuangan dan investasi, tapi juga akan semakin berhati-hati dalam memilih dan mengendalikan risiko investasi yang mereka lakukan. Salah satu instrumen investasi yang saat ini mulai diminati banyak investor yaitu reksa dana. Hal ini bisa dijadikan alternatif investasi bagi masyarakat pemodal, khususnya pemodal kecil dan pemodal yang tidak memiliki banyak waktu (Lailiyah \& Sulasmiyati, 2016). Namun, masyarakat kembali dihadapkan dalam suatu pilihan antara reksadana syariah atau reksa dana konvensional, manakah yang lebih baik diantara keduanya. Karena, pemilihan reksadana yang tepat mengharuskan investor untuk menganalisis dari sisi kinerja reksa dana tersebut.

Investor harus melihat dari sisi kinerja reksa dana karena di dalam kinerja suatu portofolio tergambarkan tingkat return dan tingkat risk dari portofolio yang nantinya akan dibeli oleh investor. Oleh karena itu, dengan menganalisa kinerja suatu portofolio, investor dapat melakukan perbandingan antara satu reksa dana dengan reksa dana lainnya dan dapat dijadikan pengambilan keputusan dalam melakukan investasi. Munculnya reksa dana syariah memang memberi pilihan investasi yang lebih banyak bagi masyarakat terutama para investor muslim, namun masih ada kekhawatiran reksadana syariah tidak mampu memberikan return yang lebih baik dibandingkan dengan reksadana konvensional.

Beberapa penelitian komparatif reksadana syariah dan reksadana konvensional telah dilakukan seperti penelitian (Lailiyah \& Sulasmiyati, 2016; Rahmah, 2016; Zamzany \& Setiawan, 2018) menjelaskan bahwasanya kinerja reksa dana konvensional lebih baik dibandingkan dengan reksadana syariah, jika menggunakan perhitungan dengan metode Sharpe dan Treynor. Jika menggunakan perhitungan dengan metode Jensen, kinerja reksadana syariah lebih baik dibandingkan dengan reksadana konvensional. Menurut (Putra \& Fauzi, 2014) reksadana syariah memiliki rata-rata kinerja yang lebih baik dari reksadana konvensional pada jenis reksa dana saham dan reksadana campuran sedangkan pada jenis pendapatan tetap reksa dana konvensional memiliki rata-rata kinerja yang lebih baik. Sedangkan, hasil penelitian (Huda et al., 2018) menyatakan bahwa tidak terdapat perbedaan yang signifikan antara return, risk, dan kinerja reksadana syariah dan reksadana konvensional.

Berdasarkan ada beberapa penelitian yang hasilnya berbeda satu dengan yang lain dan urgensinya untuk calon investor ketahui kinerja reksa dana yang lebih baik, maka peneliti akan melakukan pengembangan penelitian dengan menggunakan data reksadana lebih banyak dari penelitian sebelumnya baik itu reksadana syariah maupun reksadana konvensional dan dnegan data yang lebih up 
to date serta menggunakan 3 (tiga) metode penilaian kinerja, kemudian jenis reksadana yang diteliti yakni jenis reksadana saham karena memberikan potensi hasil yang paling tinggi. Hal tersebut peneliti lakukan dengan tujuan agar calon investor dapat menetukan pilihan investasi yang tepat entah di reksadana syariah ataukah konvensional.

\section{KAJIAN LITERATUR}

\section{A. Pasar Modal}

Menurut (Nasution, 2015) pasar modal adalah pasar yang memperjualbelikan bermacam-macam instrumen keuangan jangka panjang dengan jatuh tempo satu tahun. Pasar modal dapat dikatakan sebagai penghubung antara pihak yang memiliki dana (investor) dan pihak yang membutuhkan dana (perusahaan, institusi pemerintah, dan lainnya). Sedangkan, pasar modal syariah adalah pasar modal yang seluruh mekanisme kegiatannya khususnya terkait emiten, jenis efek yang diperdagangkan dan mekanisme perdagangannya telah dilaksanakan sesuai prinsip-prinsip syariah. Berinvestasi di sektor pasar modal merupakan salah satu cara yang dapat memudahkan dalam mencapai keinginan dan kebutuhan di masa yang akan datang.

Investasi merupakan salah satu alternatif pendanaan, baik bagi pemerintah maupun swasta. Pemerintah yang membutuhkan dana dapat menerbitkan obligasi atau surat utang dan menjualnya ke masyarakat melalui pasar modal. Demikian juga perusahaan yang membutuhkan dana dapat menerbitkan efek, baik dalam bentuk saham maupun obligasi dan menjualnya ke masyarakat melalui pasar modal. Investasi di pasar modal juga merupakan alternatif investasi yang mudah diakses oleh masyarakat luas semenjak dibukanya Bursa Efek Indonesia (Bakhri, 2018). Salah satu instrumen investasi yang sekarang sedang marak di dibicarakan adalah reksadana.

\section{B. Reksadana dan Reksadana Syariah}

Reksadana merupakan salah satu instrumen investasi untuk menghimpun dana dari masyarakat yang memiliki modal, mempunyai keinginan untuk melakukan investasi, namun hanya memiliki waktu dan pengetahuan yang terbatas (BEI, 2018). Reksadana digunakan sebagai wadah untuk menampung dana para investor yang kemudian akan diolah dan dikelola dalam sebuah portofolio oleh manajer investasi. Reksadana hadir dikarenakan pemodal mengalami kesulitan untuk berinvestasi sendiri pada surat-surat berharga tersebut. Kesulitan yang dihadapi pemodal antara lain perlunya melakukan berbagai analisis dan monitoring kondisi pasar secara terus menerus. Selain itu, dibutuhkan dana yang relatif besar untuk dapat melakukan melakukan investasi pada surat-surat berharga tersebut.

Fatwa Dewan Syariah Nasional (DSN) MUI No.20/DSN MUI/IX/2000 mendefinisikan reksa dana syariah sebagai reksa dana yang beroperasi menurut ketentuan dan prinsip syariat Islam, baik dalam bentuk akad antara pemodal dengan manajer investasi, maupun manajer investasi dengan pengguna investasi. Reksa dana syariah menurut peraturan Otoritas Jasa Keuangan adalah reksa dana sebagaimana yang dimaksud dalam Undang- 
Undang tentang Pasar Modal dan peraturan pelaksanaannya yang pengelolaannya tidak bertentangan dengan prinsip syariah di pasar modal (OJK, 2015).

\section{Perbedaan Reksa dana Syariah dengan Reksa dana Konvensional}

Menurut (Huda et al., 2018) perbedaan mendasar reksa dana konvensional dan reksa dana syariah yaitu terletak pada cara mengelola dan prinsip kebijakan investasi yang ditetapkan. Kebijakan investasi reksa dana syariah berbasis instrumen investasi dengan tata cara kelola yang halal. Halal berarti bahwa perusahaan yang mengeluarkan instrumen investasi tersebut tidak melakukan usaha-usaha yang bersinggungan dengan prinsip Islam.

Tabel 1.

Perbedaan Reksa dana Syariah dengan Reksa dana Konvensional

\begin{tabular}{|c|c|c|}
\hline Perbedaan & $\begin{array}{c}\text { Reksa dana } \\
\text { Konvensional }\end{array}$ & Reksa dana Syariah \\
\hline Tujuan investasi & $\begin{array}{l}\text { Memperoleh } \\
\text { pertumbuhan nilai } \\
\text { investasi dalam jangka } \\
\text { panjang. }\end{array}$ & $\begin{array}{l}\text { Memperoleh } \\
\text { pertumbuhan nilai } \\
\text { investasi dalam jangka } \\
\text { panjang berdasarkan } \\
\text { syariah Islam. }\end{array}$ \\
\hline Jangka waktu & Jangka panjang & Jangka pendek \\
\hline Kebijakan investasi & $\begin{array}{l}\text { Seluruh investasi yang } \\
\text { menunjang investasi. }\end{array}$ & $\begin{array}{l}\text { Investasi pada aset yang } \\
\text { sesuai dnegan anjuran } \\
\text { Dewan Syariah. }\end{array}$ \\
\hline Strategi $\mathrm{p}$ & $\begin{array}{ll}\text { - } & \text { Strategi analisis } \\
& \text { sekuritas. } \\
\text { - } & \text { Manajemen portofolio } \\
& \text { pasif. }\end{array}$ & $\begin{array}{ll} & \text { Strategi rotasi sector. } \\
\text { - } & \text { Manajemen portofolio } \\
& \text { aktif. }\end{array}$ \\
\hline $\begin{array}{l}\text { Alat ukur dan } \\
\text { evaluasi kinerja }\end{array}$ & $\begin{array}{l}\text { Dibandingkan dengan } \\
\text { indeks pasar (IHSG). }\end{array}$ & $\begin{array}{l}\text { Dibandingkan dengan } \\
\text { indeks pasar islami (JII). }\end{array}$ \\
\hline Proses filterisasi & Tidak ada. & Ada. \\
\hline
\end{tabular}

Sumber : (Rahmah, 2016)

\section{Jenis-jenis Reksadana}

Bagi calon investor memahami jenis-jenis reksadan merupakan hal yang sangat penting, karena setiap jenis reksadana memiliki karakteristik, tingkat return dan tingkat risiko yang berbeda. Menurut Mangsa Simatupang (2010 : 55), jenis-jenis reksadana yang perlu dipahami yaitu:

1. Reksadana Saham

Reksadana saham adalah reksadana yang melakukan investasi sekurangkurangnya $80 \%$ dari portofolio yang dikelolanya ke dalam efek bersifat ekuitas (saham). Reksadana saham memberikan potensi pertumbuhan nilai investasi yang paling besar demikian juga dengan risikonya.

2. Reksadana Pendapatan Tetap

Reksadana pendapatan tetap adalah reksadana yang melakukan investasi sekurang-kurangnya $80 \%$ dari portofolio yang dikelolanya ke dalam efek 
bersifat hutang, seperti obligasi. Risiko investasi yang lebih tinggi dari reksadana pasar uang membuat nilai return bagi reksadana jenis ini juga lebih tinggi, tapi tetap lebih rendah daripada reksadana campuran atau saham.

3. Reksadana Pasar Uang

Reksadana pasar uang adalah reksadana yang melakukan investasi $100 \%$ pada efek pasar uang yaitu efek hutang yang berjangka kurang dari satu tahun. Reksadana pasar uang merupakan reksadana yang memiliki risiko terendah namun juga memberikan return yang terbatas.

4. Reksadana Campuran

Reksadana campuran adalah reksadana yang melakukan investasi dalam efek ekuitas dan efek hutang yang perbandingannya tidak termasuk dalam kategori reksadana pendapatan tetap dan reksadana saham. Potensi hasil dan risiko reksadana campuran secara teoritis dapat lebih besar dari reksadana pendapatan tetap namun lebih kecil dari reksadana saham.

\section{E. Evaluasi Kinerja Reksadana}

Suatu investasi yang memiliki potensi keuntungan tinggi, tentu memiliki potensi risiko yang tinggi pula. Untuk menentukan kinerja suatu reksadana, kedua unsur tersebut memiliki hubungan yang searah dan tidak terpisah. Return adalah keuntungan yang diperoleh oleh perusahaan, individu dan institusi dari hasil kebijakan investasi yang dilakukan (Lorencia dan Taufiq, 2020). Sedangkan, risiko diartikan sebagai bentuk ketidakpastian tentang suatu keadaan yang akan terjadi nantinya (future) dengan keputusan yang diambil berdasarkan berbagai pertimbangan pada saat ini.

Reksadana berkaitan dengan Nilai Aktiva Bersih (NAB) dan unit penyertaan. NAB perunit penyertaan merupakan besaran dalam reksadana. $\mathrm{NAB} /$ unit merupakan harga beli per unit yang harus dibayar oleh investor ketika membeli reksadana. NAB dihitung dengan harga penutupan efek yang dikurangi dengan biaya yang harus dibayar. NAB/unit juga merupakan indikator kinerja investasi dalam suatu reksadana.(Lailiyah \& Sulasmiyati, 2016).

Menurut (Zamzany \& Setiawan, 2018) untuk mengetahui apakah sasaran investor masih tercapai, maka kinerja portofolio perlu dihitung dan diukur secara berkala. Mengukur kinerja reksa dana bertujuan untuk melihat bagaimana perkembangan kinerja reksa dana tersebut, sehingga dapat membantu para investor membandingkan suatu reksa dana dengan reksa dana lainnya, agar dapat mengambil keputusan berinvestasi yang tepat. Metode yang digunakan untuk mengukur kinerja reksa dana syariah dan konvensional menggunakan metode composite (risk adjusted) measures of portofolio performance yang mempertimbangkan aspek return dan risiko dalam proses pengevaluasian. Metode yang digunakan yaitu Sharpe, Treynor dan Jensen.

1. Metode Sharpe

Metode ini dikembangkan oleh William Sharpe untuk menghitung performa portofolio yang dinamakan reward-to-variability ratio (RVAR). Indeks Sharpe mendasarkan perhitungannya pada konsep garis pasar modal (capital market line) sebagai patok duga, yaitu dengan cara membagi premi risiko portofolio dengan standar deviasinya.(Putri dan 
Worokinasih., 2018) Metode sharpe diukur dengan cara membandingkan antara premi risiko portofolio dengan risiko portofolio yang dinyatakan dengan standar deviasi (risiko total). Indeks sharpe ini relevan dipergunakan untuk investor yang menanamkan dananya hanya atau sebagian besar pada portofolio tersebut, sehingga risiko portofolio dinyatakan dalam standar deviasi (Lorencia dan Taufiq, 2020).

Keterangan :

$S i=$ indeks sharpe reksadana $\mathrm{i}$

$R i=$ return reksadana $\mathrm{i}$

$R f=$ aset bebas risiko

$=$ standar deviasi reksadana $\mathrm{i}$

2. Metode Treynor

Metode treynor merupakan perbandingan antara return dengan risk dari reksadana. Namun, risiko yang dibandingkan hanya dari risiko sistematis (risiko pasar) saja yang tercermin dari nilai beta (Zamzany \& Setiawan, 2018).

Keterangan :

$T i=$ indeks treynor raksadana $\mathrm{i}$

$R i=$ return reksadana $\mathrm{i}$

$R F=$ aset bebas risiko

$=$ beta pasar $\mathrm{i}$

3. Metode Jensen

Metode jensen adalah nilai yang memperhitungkan antara selisih return yang disetahunkan dari portofolio reksadana dengan return aset bebas risiko. Pada umumnya aset bebas risiko yang digunakan adalah tingkat suku bunga acuan Bank Indonesia (Zamzany \& Setiawan, 2018).

Keterangan :

$J i=$ indeks jensen raksadana $\mathrm{i}$

$R i=$ return reksadana $\mathrm{i}$

$R f=$ aset bebas risiko

$R m=$ return bunga pasar

$=$ beta reksadana $\mathrm{i}$

\section{METODE PENELITIAN}

\section{A. Jenis Penelitian}

Jenis penelitian yang digunakan adalah jenis penelitian deskriptif kuantitatif. Fokus penelitian dibatasi ke dalam tiga objek penelitian yaitu metode Sharpe, Treynor dan Jensen. Melalui penelitian ini dapat memberikan jawaban manakah diantara kinerja reksadana saham konvensional dan reksadana saham syariah yang lebih baik. Sumber data dalam penelitian ini adalah data sekunder, berasal dari data yang dipublikasikan dalam statistik atau jurnal lainnya dan informasi yang tersedia dari berbagai sumber resmi. Lokasi penelitian dan pengambilan data dilakukan pada beberapa tempat, yaitu Otoritas Jasa Keuangan melalui website www.ojk.go.id, yahoo finance 
melalui website www.finance.yahoo.com, bareksa melalui website www.bareksa.com, Bank Indonesia melalui website www.bi.go.id, dan infovesta melalui website www.infovesta.com.

\section{B. Sampling Method}

Metode pengambilan sampel dalam penelitian ini adalah purposive sampling, yaitu pengambilan sampel yang berdasarkan pada persyaratan atau kriteria-kriteria tertentu dari peneliti. Adapun kriteria penentuan sampel yang dipertimbangkan adalah sebagai berikut:

1. Reksadana konvensional dan reksadana syariah merupakan reksadana yang tedaftar pada Otoritas Jasa Keuangan (OJK).

2. Reksadana konvensional dan reksadana syariah yang dipilih yaitu jenis reksadana saham.

3. Reksadana yang diteliti merupakan reksa dana yang sudah beraktivitas dan aktif dalam periode tahun 2014 - 2018.

\section{Populasi dan Sampel}

Populasi diambil dari reksadana konvensional dan reksadana syariah yang terdaftar di OJK periode 2014-2018 yaitu terdapat 2181 reksadana yang terdiri dari 265 reksadana syariah dan 1916 reksadana konvensional. Kemudian, jumlah reksadana syariah dengan jenis reksadana saham berjumlah 66. Sedangkan, jumlah jenis reksadana saham konvensional yaitu 208. Adapun sampel pada penelitian ini yaitu 14 reksadana syariah dan konvensional.

\section{Alat Analisis}

Analisis data yang digunakan dalam penelitian ini, yaitu:

1. Menghitung tingkat return reksadana saham syariah dan reksadana saham konvensional. Nilai ini diperoleh dari NAB (Nilai Aktiva Bersih) unit penyertaan pada tiap reksadana saham syariah maupun reksadana saham konvensional.

2. Menghitung return risk free yaitu BI rate

3. Mencari kinerja reksa dana saham syariah dihitung menggunakan metode Sharpe

4. Mencari kinerja reksa dana saham syariah dihitung menggunakan metode Treynor

5. Mencari kinerja reksa dana saham syariah dihitung menggunakan metode Jensen

6. Memberikan informasi kepada investor berdasarkan hasil perhitungan reksa dana saham syariah yang konsisten memiliki kinerja positif dengan metode Sharpe, Treynor, dan Jensen.

\section{PEMBAHASAN}

\section{A. Kinerja Reksa Dana Saham Syariah dengan Metode Sharpe Tahun 2015 $-2018$}

Berikut ini hasil pengukuran kinerja reksadana saham syariah dengan metode Sharpe periode 2015-2019: 
1. Perhitungan Reksa Dana Saham Syariah Tahun 2014 dengan Metode Sharpe

\begin{tabular}{|l|l|l|l|l|l|}
\hline No. & $\begin{array}{l}\text { Reksa Dana Saham } \\
\text { Syariah }\end{array}$ & \multicolumn{1}{|c|}{$\boldsymbol{R i}$} & \multicolumn{1}{|c|}{$\begin{array}{c}\text { Standar } \\
\text { Deviasi }\end{array}$} & Sharpe \\
\hline 1. & $\begin{array}{l}\text { Batavia Dana Saham } \\
\text { Syariah }\end{array}$ & 0.01586 & 0.00620 & 0,0493 & 0,3078 \\
\hline 2. & Trim Syariah Saham & 0.02222 & 0.00620 & 0,0461 & 0.5679 \\
\hline 3. & $\begin{array}{l}\text { CIMB Principal } \\
\text { Islamic Euity }\end{array}$ & 0.02218 & 0.00620 & 0,0380 & 0.5452 \\
\hline 4. & PNM Ekuitas Syariah & 0.01585 & 0.00620 & 0,0465 & 0.2536 \\
\hline 5. & $\begin{array}{l}\text { Mandiri Investa } \\
\text { Ekuitas Syariah }\end{array}$ & 0.01626 & 0.00620 & 0,0580 & 0.4102 \\
\hline 6. & $\begin{array}{l}\text { Cipta Syariah Euity } \\
\text { M. Syariah }\end{array}$ & $\begin{array}{l}\text { Manulife } 0.01936 \\
\text { Sektoral Amanah }\end{array}$ & 0.00620 & 0,0437 & 0.5933 \\
\hline
\end{tabular}

Berdasarkan tabel hasil perhitungan di atas, terdapat 7 reksadana saham syariah yang menghasilkan kinerja positif. Hal ini menunjukkan bahwa 7 reksadana saham syariah tersebut layak dijadikan sebagai tempat investasi. Kisaran nilai indeks Sharpe dalam penelitian ini adalah antara 0,5933 oleh Cipta Syariah Equity sampai yang paling rendah sebesar 0,2536 oleh saham PNM Ekuitas Syariah.

2. Perhitungan Reksa Dana Saham Syariah Tahun 2015 dengan Metode Sharpe

\begin{tabular}{|c|c|c|c|c|c|}
\hline No. & $\begin{array}{c}\text { Reksa Dana Saham } \\
\text { Syariah }\end{array}$ & $R i$ & $R f$ & $\begin{array}{r}\text { Standar } \\
\text { Deviasi }\end{array}$ & Sharpe \\
\hline 1. & $\begin{array}{l}\text { Batavia Dana Saham } \\
\text { Syariah }\end{array}$ & $-0,0131$ & 0,0063 & 0,0423 & $-0,4589$ \\
\hline 2. & Trim Syariah Saham & $-0,0144$ & 0,0063 & 0,0437 & $-0,4728$ \\
\hline 3. & $\begin{array}{l}\text { CIMB Principal } \\
\text { Islamic Euity }\end{array}$ & $-0,0211$ & 0,0063 & 0,0480 & $-0,5699$ \\
\hline 4. & PNM Ekuitas Syariah & $-0,0267$ & 0,0063 & 0,0365 & $-0,9036$ \\
\hline 5. & $\begin{array}{l}\text { Mandiri Investa } \\
\text { Ekuitas Syariah }\end{array}$ & $-0,0144$ & 0,0063 & 0,0500 & $-0,4131$ \\
\hline 6. & Cipta Syariah Equity & $-0,0116$ & 0,0063 & 0,0461 & $-0,3886$ \\
\hline 7. & $\begin{array}{l}\text { Manulife Syariah } \\
\text { Sektoral Amanah }\end{array}$ & -0.0111 & 0.0063 & 0.0493 & -0.3518 \\
\hline
\end{tabular}

Berdasarkan tabel hasil perhitungan di atas, menunjukkan bahwa 7 reksadana saham syariah tidak ada yang menghasilkan kinerja positif. Hal ini terjadi karena return investasi bebas risiko lebih besar dari return reksadana saham syariah. Kisaran nilai indeks Sharpe dalam penelitian ini adalah antara -0.3518 oleh Manulife Syariah Sektoral Amanah sampai yang paling rendah sebesar -0,9036 oleh saham PNM Ekuitas Syariah.

\section{Perhitungan Reksa Dana Saham Syariah Tahun 2016 dengan Metode Sharpe}




\begin{tabular}{|c|c|c|c|c|c|}
\hline No. & $\begin{array}{l}\text { Reksa Dana Saham } \\
\text { Syariah }\end{array}$ & $\mathbf{R i}$ & $\mathbf{R f}$ & $\begin{array}{l}\text { Standar } \\
\text { Deviasi }\end{array}$ & Sharpe \\
\hline 1. & $\begin{array}{l}\text { Batavia Dana Saham } \\
\text { Syariah }\end{array}$ & 0,0111 & 0,0050 & 0,0347 & 0,1759 \\
\hline 2. & Trim Syariah Saham & 0,0124 & 0,0050 & 0,0327 & 0,2274 \\
\hline 3. & $\begin{array}{l}\text { CIMB Principal } \\
\text { Islamic Euity }\end{array}$ & 0,0086 & 0,0050 & 0,0354 & 0,1029 \\
\hline 4. & $\begin{array}{ll}\text { PNM } & \text { Ekuitas } \\
\text { Syariah } & \end{array}$ & 0,0121 & 0,0050 & 0,0313 & 0,2255 \\
\hline 5. & $\begin{array}{l}\text { Mandiri Investa } \\
\text { Ekuitas Syariah }\end{array}$ & 0,0098 & 0,0050 & 0,0355 & 0,1364 \\
\hline 6. & Cipta Syariah Euity & 0,0095 & 0,0063 & 0,0348 & 0,1298 \\
\hline 7. & $\begin{array}{l}\text { Manulife Syariah } \\
\text { Sektoral Amanah }\end{array}$ & 0,0122 & 0.0063 & 0,0339 & 0,2124 \\
\hline
\end{tabular}

Berdasarkan tabel hasil di atas, terdapat 7 reksadana saham syariah yang menghasilkan kinerja positif. Hal ini menunjukkan bahwa 7 reksa dana saham syariah berdasarkan metode Sharpe layak dijadikan sebagai tempat investasi. Kisaran nilai indeks Sharpe dalam penelitian ini adalah antara 0,2274 oleh Trim Syariah Saham sampai yang paling rendah sebesar 0,1029 oleh saham CIMB Principal Islamic Equity.

4. Perhitungan Reksa Dana Saham Syariah Tahun 2017 dengan Metode Sharpe

\begin{tabular}{|c|c|c|c|c|c|}
\hline No. & $\begin{array}{l}\text { Reksa Dana Saham } \\
\text { Syariah }\end{array}$ & $\mathbf{R i}$ & $\mathbf{R f}$ & $\begin{array}{l}\text { Standar } \\
\text { Deviasi }\end{array}$ & Sharpe \\
\hline 1. & $\begin{array}{l}\text { Batavia Dana Saham } \\
\text { Syariah }\end{array}$ & 0.0049 & 0,0038 & 0.0229 & 0.0480 \\
\hline 2. & Trim Syariah Saham & 0.0047 & 0,0038 & 0.0219 & 0.0411 \\
\hline 3. & $\begin{array}{l}\text { CIMB Principal } \\
\text { Islamic Euity }\end{array}$ & 0.0003 & 0,0038 & 0.0209 & -0.1678 \\
\hline 4. & $\begin{array}{ll}\text { PNM } & \text { Ekuitas } \\
\text { Syariah } & \\
\end{array}$ & 0.0045 & 0,0038 & 0.0220 & 0.0318 \\
\hline 5. & $\begin{array}{l}\text { Mandiri Investa } \\
\text { Ekuitas Syariah }\end{array}$ & 0.0028 & 0,0038 & 0.0197 & -0.0506 \\
\hline 6. & Cipta Syariah Euity & 0.0030 & 0,0038 & 0.0236 & -0.0340 \\
\hline 7. & $\begin{array}{l}\text { Manulife Syariah } \\
\text { Sektoral Amanah }\end{array}$ & 0.0002 & 0,0038 & 0.0171 & -0.2107 \\
\hline
\end{tabular}

Berdasarkan tabel hasil perhitungan di atas, terdapat 3 reksadana saham syariah yang menghasilkan kinerja positif dan 4 reksadana saham syariah yang menghasilkan kinerja. Hal ini menunjukkan bahwa 3 reksa dana saham syariah berdasarkan metode Sharpe layak dijadikan sebagai tempat investasi, yaitu Batavia Dana Saham Syariah, Trim Syariah Saham dan PNM Ekuitas Syariah. Kisaran nilai indeks Sharpe dalam penelitian 
ini adalah antara 0.0480 oleh Batavia Dana Saham Syariah sampai yang paling rendah sebesar -0,1678 oleh saham CIMB Principal Islamic Equity.

5. Perhitungan Reksa Dana Saham Syariah Tahun 2018 dengan Metode Sharpe

\begin{tabular}{|l|l|l|l|l|l|}
\hline No. & $\begin{array}{l}\text { Reksa Dana Saham } \\
\text { Syariah }\end{array}$ & $\mathbf{R i}$ & $\mathbf{R f}$ & $\begin{array}{l}\text { Standar } \\
\text { Deviasi }\end{array}$ & Sharpe \\
\hline 1. & $\begin{array}{l}\text { Batavia Dana Saham } \\
\text { Syariah }\end{array}$ & -0.0001 & 0.0002 & 0.0138 & $-0,0196$ \\
\hline 2. & Trim Syariah Saham & -0.0001 & 0.0002 & 0.0137 & -0.0196 \\
\hline 3. & $\begin{array}{l}\text { CIMB Principal } \\
\text { Islamic Equity }\end{array}$ & -0.0004 & 0,0016 & 0.0121 & -0.0495 \\
\hline 4. & $\begin{array}{l}\text { PNM Ekuitas } \\
\text { Syariah } 0.0006\end{array}$ & 0,0002 & 0.0134 & $-0,0579$ \\
\hline 5. & $\begin{array}{l}\text { Mandiri Investa } \\
\text { Ekuitas Syariah }\end{array}$ & -0.0002 & 0,0002 & 0.0124 & -0.0320 \\
\hline 6. & $\begin{array}{l}\text { Cipta Syariah Equity } \\
7 .\end{array}$ & -0.0006 & 0,0002 & 0.0133 & -0.0546 \\
\hline Manulife Syariah & -0.0006 & 0,0002 & 0.0123 & -0.0621 \\
\hline
\end{tabular}

Berdasarkan tabel hasil perhitungan di atas, terdapat 7 reksadana saham syariah yang semuanya menghasilkan kinerja negatif. Hal ini menunjukkan bahwa 7 reksa dana saham syariah tersebut kurang layak dijadikan sebagai tempat investasi. Kinerja reksa dana saham syariah dengan hasil negatif menunjukkan bahwa return yang diperoleh lebih rendah dari return investasi bebas risiko. Kisaran nilai indeks Sharpe dalam penelitian ini adalah antara -0,0196 oleh Batavia Dana Saham Syariah dan Trim Syariah Saham sampai yang paling rendah sebesar 0,0621 oleh saham Manulife Syariah Sektoral Amanah.

\section{B. Kinerja Reksa Dana Saham Syariah dengan Metode Treynor Tahun 2015 $-2018$}

Berikut ini hasil pengukuran kinerja reksadana saham syariah dengan metode Treynor periode 2015-2018:

1. Perhitungan Reksa Dana Saham Syariah Tahun 2014 dengan Metode Treynor

\begin{tabular}{|l|l|l|l|l|l|}
\hline No. & $\begin{array}{l}\text { Reksa Dana Saham } \\
\text { Syariah }\end{array}$ & \multicolumn{1}{|c|}{ Ri } & \multicolumn{1}{|c|}{ Rf } & & Treynor \\
\hline 1. & $\begin{array}{l}\text { Batavia Dana Saham } \\
\text { Syariah }\end{array}$ & 0.01586 & 0.00620 & $\begin{array}{l}1.115970 \\
432\end{array}$ & $\begin{array}{l}0.00865 \\
2926\end{array}$ \\
\hline 2. & Trim Syariah Saham & 0.02222 & 0.00620 & $\begin{array}{l}1.047500 \\
482\end{array}$ & $\begin{array}{l}0.01529 \\
0823\end{array}$ \\
\hline 3. & CIMB Principal & 0.02218 & 0.00620 & 1,101475 & 0.01451 \\
\hline
\end{tabular}




\begin{tabular}{|l|l|l|l|l|l|}
\hline & Islamic Euity & & & 87 & 2876 \\
\hline 4. & PNM Ekuitas Syariah & 0.01585 & 0.00620 & $\begin{array}{l}0.950309 \\
603\end{array}$ & $\begin{array}{l}0.01015 \\
4576\end{array}$ \\
\hline 5. & $\begin{array}{l}\text { Mandiri Investa } \\
\text { Ekuitas Syariah }\end{array}$ & 0.01626 & 0.00620 & $\begin{array}{l}0.952358 \\
561\end{array}$ & $\begin{array}{l}0.01056 \\
9185\end{array}$ \\
\hline 6. & Cipta Syariah Equity & 0.01936 & 0.00620 & $\begin{array}{l}0.852517 \\
863\end{array}$ & $\begin{array}{l}0.01543 \\
3764\end{array}$ \\
\hline 7. & $\begin{array}{l}\text { Manulife Syariah } \\
\text { Sektoral Amanah }\end{array}$ & 0.01697 & 0.00620 & $\begin{array}{l}0.989892 \\
753\end{array}$ & $\begin{array}{l}0.01088 \\
604\end{array}$ \\
\hline
\end{tabular}

Berdasarkan tabel hasil di atas, terdapat 7 reksadana saham syariah yang menghasilkan kinerja positif. Hal ini menunjukkan bahwa 7 reksa dana saham syariah berdasarkan metode Treynor layak dijadikan sebagai tempat investasi. Kinerja reksa dana saham syariah dengan hasil positif menunjukkan bahwa return yang diperoleh lebih besar dari return investasi bebas risiko. Kisaran nilai indeks Treynor dalam penelitian ini adalah antara 0.015433764 oleh Cipta Syariah Equity Saham sampai yang paling rendah sebesar 0.008652926 oleh saham Batavia Dana Saham Syariah.

2. Perhitungan Reksa Dana Saham Syariah Tahun 2015 dengan Metode Treynor

\begin{tabular}{|l|l|l|l|l|l|}
\hline No. & $\begin{array}{l}\text { Reksa Dana Saham } \\
\text { Syariah }\end{array}$ & \multicolumn{1}{|c|}{ Ri } & Rf & & Treynor \\
\hline 3. & $\begin{array}{l}\text { Batavia Dana Saham } \\
\text { Syariah }\end{array}$ & $-0,0131$ & 0,0063 & 0,7834 & $-0,0248$ \\
\hline 2. & Trim Syariah Saham & $-0,0144$ & 0,0063 & 0,8312 & $-0,0249$ \\
\hline 3. & $\begin{array}{l}\text { CIMB Principal } \\
\text { Islamic Equity }\end{array}$ & $-0,0211$ & 0,0063 & 0,8983 & $-0,0305$ \\
\hline 4. & PNM Ekuitas Syariah & $-0,0267$ & 0,0063 & 0,6709 & $-0,0492$ \\
\hline 5. & $\begin{array}{l}\text { Mandiri Investa } \\
\text { Ekuitas Syariah }\end{array}$ & $-0,0144$ & 0,0063 & 0,9328 & $-0,0222$ \\
\hline 6. & Cipta Syariah Euity & $-0,0116$ & 0,0063 & 0,8657 & $-0,0207$ \\
\hline 7. & $\begin{array}{l}\text { Manulife Syariah } \\
\text { Sektoral Amanah }\end{array}$ & -0.0111 & 0.0063 & 0,9470 & $-0,0183$ \\
\hline
\end{tabular}

Berdasarkan tabel hasil perhitungan kinerja di atas, terdapat 7 sampel penelitian reksadana saham syariah yang semuanya menghasilkan kinerja negatif. Hal ini menunjukkan bahwa 7 reksa dana saham syariah tersebut kurang layak dijadikan sebagai tempat investasi, Kisaran nilai indeks Sharpe dalam penelitian ini adalah antara -0,0492 oleh PNM Ekuitas Syariah dan Trim Syariah Saham sampai yang paling rendah sebesar -0,0183 oleh saham Manulife Syariah Sektoral Amanah. 
2. Perhitungan Reksa Dana Saham Syariah Tahun 2016 dengan Metode Treynor

\begin{tabular}{|l|l|l|l|l|l|}
\hline No. & $\begin{array}{l}\text { Reksa Dana Saham } \\
\text { Syariah }\end{array}$ & \multicolumn{1}{|c|}{ Ri } & Rf & Treynor \\
\hline 1. & $\begin{array}{l}\text { Batavia Dana Saham } \\
\text { Syariah }\end{array}$ & 0.0111 & 0.0050 & 0.8671 & 0.0070 \\
\hline 2. & Trim Syariah Saham & 0.0124 & 0.0050 & 0,8218 & 0,0090 \\
\hline 3. & $\begin{array}{l}\text { CIMB Principal } \\
\text { Islamic Euity }\end{array}$ & 0.0086 & 0.0050 & 0,9353 & 0,0039 \\
\hline 4. & PNM Ekuitas Syariah & 0.0121 & 0.0050 & 0,8018 & 0,0088 \\
\hline 5. & $\begin{array}{l}\text { Mandiri Investa } \\
\text { Ekuitas Syariah }\end{array}$ & 0.0098 & 0.0050 & 0,9054 & 0,0053 \\
\hline 6. & $\begin{array}{l}\text { Cipta Syariah Euity } \\
\text { Manulife Syariah }\end{array}$ & 0.0095 & 0.0050 & 0,9044 & 0,0050 \\
\hline & \begin{tabular}{l} 
Sektoral Amanah \\
\hline
\end{tabular} & 0.0050 & 0,8557 & 0,0084 \\
\hline
\end{tabular}

Berdasarkan tabel hasil perhitungan kinerja di atas, terdapat 7 reksadana saham syariah yang menghasilkan kinerja positif. Hal ini menunjukkan bahwa 7 reksa dana saham syariah berdasarkan metode Treynor layak dijadikan sebagai tempat investasi. Kinerja reksa dana saham syariah dengan hasil positif menunjukkan bahwa return yang diperoleh lebih besar dari return investasi bebas risiko. Kisaran nilai indeks Treynor dalam penelitian ini adalah antara 0,0090 oleh Trim Syariah Saham sampai yang paling rendah sebesar 0,0039 oleh saham CIMB Principal Islamic Equity.

3. Perhitungan Reksa Dana Saham Syariah Tahun 2017 dengan Metode Treynor

\begin{tabular}{|l|l|l|l|l|l|}
\hline No. & $\begin{array}{l}\text { Reksa Dana Saham } \\
\text { Syariah }\end{array}$ & \multicolumn{1}{|c|}{ Ri } & Rf & & Treynor \\
\hline 1. & $\begin{array}{l}\text { Batavia Dana Saham } \\
\text { Syariah }\end{array}$ & 0.0049 & 0.0038 & 0.9079 & 0.0012 \\
\hline 2. & Trim Syariah Saham & 0.0047 & 0.0038 & 0.6545 & 0.0014 \\
\hline 3. & $\begin{array}{l}\text { CIMB Principal } \\
\text { Islamic Euity }\end{array}$ & 0.0003 & 0.0038 & 0.7562 & -0.0046 \\
\hline 4. & PNM Ekuitas Syariah & 0.0045 & 0.0038 & 0.8487 & 0.0008 \\
\hline 5. & $\begin{array}{l}\text { Mandiri Investa } \\
\text { Ekuitas Syariah }\end{array}$ & 0.0028 & 0.0038 & 0.7481 & -0.0013 \\
\hline 6. & $\begin{array}{l}\text { Cipta Syariah Euity } \\
\text { M. Syariah }\end{array}$ & 0.0030 & 0.00038 & 0.8809 & -0.0009 \\
\hline & \begin{tabular}{l} 
Manulife Sektoral Amanah \\
\hline
\end{tabular} & 0.0038 & 0.5677 & -0.0063 \\
\hline
\end{tabular}

Berdasarkan tabel hasil perhitungan kinerja di atas, terdapat 3 reksadana saham syariah yang menghasilkan kinerja positif dan 4 reksadana saham syariah yang menghasilkan kinerja. Hal ini menunjukkan bahwa 3 reksa dana saham syariah berdasarkan metode Treynor layak dijadikan sebagai tempat investasi, yaitu Batavia Dana Saham Syariah, 
Trim Syariah Saham dan PNM Ekuitas Syariah. Kisaran nilai indeks Treynor dalam penelitian ini adalah antara 0,0014 oleh Trim Syariah Saham sampai yang paling rendah sebesar -0,0063 oleh saham Manulife Syariah Sektoral Amanah.

4. Perhitungan Reksa Dana Saham Syariah Tahun 2018 dengan Metode Treynor

\begin{tabular}{|c|c|c|c|c|c|}
\hline No. & $\begin{array}{c}\text { Reksa Dana Saham } \\
\text { Syariah }\end{array}$ & $\mathbf{R i}$ & $\mathbf{R f}$ & & Treynor \\
\hline 1. & $\begin{array}{l}\text { Batavia Dana Saham } \\
\text { Syariah }\end{array}$ & -0.0001 & 0.0002 & 1.2002 & -0.0002 \\
\hline 2. & Trim Syariah Saham & -0.0001 & 0.0002 & 1.1895 & -0.0002 \\
\hline 3. & $\begin{array}{l}\text { CIMB Principal } \\
\text { Islamic Euity }\end{array}$ & -0.0004 & 0.0016 & 1.0557 & -0.0006 \\
\hline 4. & PNM Ekuitas Syariah & -0.0006 & 0.0002 & 1.1652 & -0.0007 \\
\hline 5. & $\begin{array}{l}\text { Mandiri Investa } \\
\text { Ekuitas Syariah }\end{array}$ & -0.0002 & 0.0002 & 1.0832 & -0.0004 \\
\hline 6. & Cipta Syariah Euity & -0.0006 & 0.0002 & 1.1632 & -0.0006 \\
\hline 7. & $\begin{array}{l}\text { Manulife Syariah } \\
\text { Sektoral Amanah }\end{array}$ & -0.0006 & 0.0002 & 1.0738 & -0.0007 \\
\hline
\end{tabular}

Berdasarkan tabel hasil perhitungan kinerja di atas, terdapat 7 reksadana saham syariah yang menghasilkan kinerja negatif. Hal ini menunjukkan bahwa 7 reksa dana saham syariah berdasarkan metode Treynor tersebut kurang layak dijadikan sebagai tempat investasi, Kinerja reksa dana saham syariah dengan hasil negatif menunjukkan bahwa return yang diperoleh lebih rendah dari return investasi bebas risiko. Kisaran nilai indeks Treynor dalam penelitian ini adalah antara -0,0002 oleh Batavia Dana Saham Syariah, Trim Syariah Saham sampai yang paling rendah sebesar -0,0007 oleh saham Manulife Syariah Sektoral Amanah dan PNM Ekuitas Syariah,

\section{Kinerja Reksa Dana Saham Syariah dengan Metode Jensen Tahun 2014 - 2018}

Berikut ini hasil pengukuran kinerja reksadana saham syariah dengan metode Jensen periode 2015-2018:

1. Perhitungan Reksa Dana Saham Syariah Tahun 2014 dengan Metode Jensen

\begin{tabular}{|l|l|l|l|l|l|l|}
\hline No. & $\begin{array}{l}\text { Reksa Dana Saham } \\
\text { Syariah }\end{array}$ & \multicolumn{1}{|c|}{$\boldsymbol{R i}$} & $\boldsymbol{R f}$ & & $\boldsymbol{R m}$ & Jensen \\
\hline 1. & $\begin{array}{l}\text { Batavia Dana Saham } \\
\text { Syariah }\end{array}$ & 0.01586 & 0.00620 & $\begin{array}{l}1.115970 \\
432\end{array}$ & 0.01417 & $\begin{array}{l}0.00220 \\
5603\end{array}$ \\
\hline 2. & Trim Syariah Saham & 0.02222 & 0.00620 & $\begin{array}{l}1.047500 \\
482\end{array}$ & 0.01417 & $\begin{array}{l}0.00767 \\
0547\end{array}$ \\
\hline 3. & $\begin{array}{l}\text { CIMB Principal } \\
\text { Islamic Equity }\end{array}$ & 0.02218 & 0.00620 & $\begin{array}{l}1,101475 \\
87\end{array}$ & 0.01417 & $\begin{array}{l}0.00922 \\
5649\end{array}$ \\
\hline 4. & PNM Ekuitas Syariah & 0.01585 & 0.00620 & 0.950309 & 0.01417 & - \\
\hline
\end{tabular}




\begin{tabular}{|c|c|c|c|c|c|c|}
\hline & & & & 603 & & $\begin{array}{l}0.05345 \\
0379\end{array}$ \\
\hline 5. & $\begin{array}{l}\text { Mandiri Investa } \\
\text { Ekuitas Syariah }\end{array}$ & 0.01626 & 0.00620 & $\begin{array}{l}0.952358 \\
561\end{array}$ & 0.01417 & $\begin{array}{l}0.00395 \\
5729\end{array}$ \\
\hline 6. & Cipta Syariah Euity & 0.01936 & 0.00620 & $\begin{array}{l}0.852517 \\
863\end{array}$ & 0.01417 & $\begin{array}{l}- \\
0.02241 \\
0893\end{array}$ \\
\hline 7. & $\begin{array}{l}\text { Manulife Syariah } \\
\text { Sektoral Amanah }\end{array}$ & 0.01697 & 0.00620 & $\begin{array}{l}0.989892 \\
753\end{array}$ & 0.01417 & $\begin{array}{l}0.00288 \\
8439\end{array}$ \\
\hline
\end{tabular}

Berdasarkan tabel hasil perhitungan kinerja di atas, terdapat 5 reksadana saham syariah yang menghasilkan kinerja positif dan 2 reksadana saham syariah yang menghasilkan kinerja negatif. Hal ini menunjukkan bahwa 5 reksa dana saham syariah berdasarkan metode Jensen tersebut layak dijadikan sebagai tempat investasi, yaitu Batavia Dana Saham Syariah, Trim Syariah Saham, CIMB Principal Islamic Equity, Mandiri Investa Ekuitas Syariah, dan Manulife Syariah Sektoral Amanah. Kisaran nilai indeks Jensen dalam penelitian ini adalah antara 0.009225649 oleh CIMB Principal Islamic Equity sampai yang paling rendah sebesar -0.053450379 oleh saham PNM Ekuitas Syariah.

2. Perhitungan Reksa Dana Saham Syariah Tahun 2015 dengan Metode Jensen

\begin{tabular}{|c|c|c|c|c|c|c|}
\hline No. & $\begin{array}{c}\text { Reksa Dana Saham } \\
\text { Syariah }\end{array}$ & $R i$ & $R f$ & & $R m$ & Jensen \\
\hline 2. & $\begin{array}{l}\text { Batavia Dana Saham } \\
\text { Syariah }\end{array}$ & -0.0131 & 0.0063 & 0.7834 & -0.0100 & -0.0066 \\
\hline 2. & Trim Syariah Saham & -0.0144 & 0.0063 & 0.8312 & -0.0100 & -0.0071 \\
\hline 3. & $\begin{array}{l}\text { CIMB Principal } \\
\text { Islamic Equity }\end{array}$ & -0.0211 & 0.0063 & 0.8983 & -0.0100 & -0.0127 \\
\hline 4. & PNM Ekuitas Syariah & -0.0267 & 0.0063 & 0.6709 & -0.0100 & -0.0221 \\
\hline 5. & $\begin{array}{l}\text { Mandiri Investa } \\
\text { Ekuitas Syariah }\end{array}$ & -0.0128 & 0.0063 & 0.8804 & -0.0100 & -0.0047 \\
\hline 6. & Cipta Syariah Equity & -0.0116 & 0.0063 & 0.8657 & -0.0100 & -0.0038 \\
\hline 7. & $\begin{array}{l}\text { Manulife Syariah } \\
\text { Sektoral Amanah }\end{array}$ & -0.0111 & 0.0063 & 0.9470 & -0.0100 & -0.0019 \\
\hline
\end{tabular}

Berdasarkan tabel hasil perhitungan kinerja di atas, terdapat 7 sampel reksadana saham syariah yang semuanya menghasilkan kinerja negatif. Hal ini menunjukkan bahwa 7 reksa dana saham syariah tersebut kurang layak dijadikan sebagai tempat investasi, Kinerja reksa dana saham syariah dengan hasil negatif menunjukkan bahwa actual return yang diperoleh lebih rendah dari expected return. Kisaran nilai indeks Jensen dalam penelitian ini adalah antara -0,0019 oleh Manulife Syariah Sektoral Amanah sampai yang paling rendah sebesar -0,0221 oleh saham PNM Ekuitas Syariah.

3. Perhitungan Reksa Dana Saham Syariah Tahun 2016 dengan Metode Jensen

\begin{tabular}{|l|c|c|c|c|c|c|}
\hline No. & $\begin{array}{c}\text { Reksa Dana Saham } \\
\text { Syariah }\end{array}$ & $\boldsymbol{R i}$ & $\boldsymbol{R} \boldsymbol{f}$ & & $\boldsymbol{R m}$ & Jensen \\
\hline 1. & Batavia Dana Saham & 0.0111 & 0.0050 & 0.8671 & 0.0128 & -0.0007 \\
\hline
\end{tabular}




\begin{tabular}{|l|l|l|l|l|l|l|}
\hline & Syariah & & & & & \\
\hline 2. & Trim Syariah Saham & 0.0124 & 0.0050 & 0.8218 & 0.0128 & 0.0010 \\
\hline 3. & $\begin{array}{l}\text { CIMB Principal } \\
\text { Islamic Equity }\end{array}$ & 0.0086 & 0.0050 & 0.9353 & 0.0128 & -0.0037 \\
\hline 4. & PNM Ekuitas Syariah & 0.0121 & 0.0050 & 0.8018 & 0.0128 & 0.0008 \\
\hline 5. & $\begin{array}{l}\text { Mandiri Investa } \\
\text { Ekuitas Syariah }\end{array}$ & 0.0098 & 0.0050 & 0.9054 & 0.0128 & -0.0022 \\
\hline 6. & Cipta Syariah Equity & 0.0095 & 0.0050 & 0.9044 & 0.0128 & -0.0025 \\
\hline 7. & $\begin{array}{l}\text { Manulife Syariah } \\
\text { Sektoral Amanah }\end{array}$ & 0.0122 & 0.0050 & 0.8557 & 0.0128 & 0.0005 \\
\hline
\end{tabular}

Berdasarkan tabel hasil perhitungan kinerja di atas, terdapat 3 reksadana saham syariah yang menghasilkan kinerja positif dan 4 reksadana saham syariah yang menghasilkan kinerja negatif. Hal ini menunjukkan bahwa 3 reksa dana saham syariah berdasarkan metode Jensen tersebut layak dijadikan sebagai tempat investasi, yaitu Trim Syariah Saham, PNM Ekuitas Syariah dan Manulife Syariah Sektoral Amanah. Kinerja reksa dana saham syariah dengan hasil positif menunjukkan bahwa actual return yang diperoleh lebih tinggi dari expected return. Kisaran nilai indeks Jensen dalam penelitian ini adalah antara 0,0010 oleh Trim Syariah Saham sampai yang paling rendah sebesar -0,0037 oleh saham CIMB Principal Islamic Equity.

\section{Perhitungan Reksa Dana Saham Syariah Tahun 2017 dengan Metode} Jensen

\begin{tabular}{|c|c|c|c|c|c|c|}
\hline No. & $\begin{array}{c}\text { Reksa Dana Saham } \\
\text { Syariah } \\
\end{array}$ & $R i$ & $R f$ & & $R m$ & Jensen \\
\hline 1. & $\begin{array}{l}\text { Batavia Dana Saham } \\
\text { Syariah }\end{array}$ & 0.0049 & 0.0038 & 0.9079 & 0.0074 & -0.0022 \\
\hline 2. & Trim Syariah Saham & 0.0047 & 0.0038 & 0.6545 & 0.0074 & -0.0015 \\
\hline 3. & $\begin{array}{l}\text { CIMB Principal } \\
\text { Islamic Equity }\end{array}$ & 0.0003 & 0.0038 & 0.7562 & 0.0074 & -0.0062 \\
\hline 4. & PNM Ekuitas Syariah & 0.0045 & 0.0038 & 0.8487 & 0.0074 & -0.0024 \\
\hline 5. & $\begin{array}{l}\text { Mandiri Investa } \\
\text { Ekuitas Syariah }\end{array}$ & 0.0028 & 0.0038 & 0.7481 & 0.0074 & -0.0037 \\
\hline 6. & Cipta Syariah Equity & 0.0030 & 0.0038 & 0.8809 & 0.0074 & -0.0040 \\
\hline 7. & $\begin{array}{l}\text { Manulife Syariah } \\
\text { Sektoral Amanah }\end{array}$ & 0.0002 & 0.0038 & 0.5677 & 0.0074 & -0.0056 \\
\hline
\end{tabular}

Berdasarkan tabel hasil perhitungan kinerja di atas, terdapat 7 reksadana saham syariah yang menghasilkan kinerja negatif. Hal ini menunjukkan bahwa 7 reksa dana saham syariah berdasarkan metode Jensen tersebut kurang layak dijadikan sebagai tempat investas. Kinerja reksa dana saham syariah dengan hasil negatif menunjukkan bahwa actual return yang diperoleh lebih rendah dari expected return. Kisaran nilai indeks Jensen dalam penelitian ini adalah antara 0,0015 oleh Trim Syariah Saham sampai yang paling rendah sebesar -0,0062 oleh saham CIMB Principal Islamic Equity.

\section{Perhitungan Reksa Dana Saham Syariah Tahun 2018 dengan Metode Jensen}

\begin{tabular}{|l|l|l|l|l|l|}
\hline No. & Reksa Dana Saham & $R i$ & $R f$ & $R m$ & Jensen \\
\hline
\end{tabular}




\begin{tabular}{|c|c|c|c|c|c|}
\hline & Syariah & & & & \\
\hline 1. & $\begin{array}{l}\text { Batavia Dana Saham } \\
\text { Syariah }\end{array}$ & -0.0001 & 0.0002 & -0.0005 & -0.0003 \\
\hline 2. & Trim Syariah Saham & -0.0001 & 0.0002 & -0.0005 & -0.0003 \\
\hline 3. & $\begin{array}{l}\text { CIMB Principal } \\
\text { Islamic Equity }\end{array}$ & -0.0004 & 0.0016 & -0.0005 & -0.0001 \\
\hline 4. & PNM Ekuitas Syariah & -0.0006 & 0.0002 & -0.0005 & -0.0002 \\
\hline 5. & $\begin{array}{l}\text { Mandiri Investa } \\
\text { Ekuitas Syariah }\end{array}$ & -0.0002 & 0.0002 & -0.0005 & -0.0015 \\
\hline 6. & Cipta Syariah Equity & -0.0006 & 0.0002 & -0.0005 & -0.0001 \\
\hline 7. & $\begin{array}{l}\text { Manulife Syariah } \\
\text { Sektoral Amanah }\end{array}$ & -0.0006 & 0.0002 & -0.0005 & -0.0002 \\
\hline
\end{tabular}

Berdasarkan tabel hasil perhitungan kinerja di atas, terdapat 7 reksadana saham syariah yang menghasilkan kinerja negatif. Hal ini menunjukkan bahwa 7 reksa dana saham syariah berdasarkan metode Jensen tersebut kurang layak dijadikan sebagai tempat investasi. Kisaran nilai indeks Jensen dalam penelitian ini adalah antara -0,0001 oleh CIMB Principal Islamic Equity dan Cipta Syariah Equity sampai yang paling rendah sebesar -0,0015 oleh saham Mandiri Investa Ekuitas Syariah. Kinerja reksa dana saham syariah dengan hasil negatif menunjukkan bahwa actual return yang diperoleh lebih rendah dari expected return.

\section{A. Kinerja Reksa Dana Saham Konvensional dengan Metode Sharpe Tahun $2014-2018$}

1. Perhitungan Reksa Dana Saham Konvensional Tahun 2014 dengan Metode Sharpe

\begin{tabular}{|l|l|c|}
\hline No. & \multicolumn{1}{|c|}{$\begin{array}{c}\text { Reksa Dana Saham } \\
\text { Konvensional }\end{array}$} & Sharpe \\
\hline 1. & BNP Paribas Ekuitas & 0,6847 \\
\hline 2. & MNC Dana Ekuitas & 0,3350 \\
\hline 3. & Manulife Saham Andalan & 0,5814 \\
\hline 4. & $\begin{array}{l}\text { RHB Alpha Sector } \\
\text { Rotation }\end{array}$ & 0,7736 \\
\hline 5. & Simas Saham Unggulan & 0,6847 \\
\hline 6. & TRIM Kapital & 0,6895 \\
\hline 7. & $\begin{array}{l}\text { CIMB Principal Total } \\
\text { Return Equity Fund }\end{array}$ & 0,6541 \\
\hline
\end{tabular}

Berdasarkan tabel hasil perhitungan kinerja di atas, terdapat 7 reksadana saham konvensional yang menghasilkan kinerja positif dari. Hal ini menunjukkan bahwa 7 reksa dana saham konvensional tersebut layak dijadikan sebagai tempat investas. Kisaran nilai indeks Sharpe dalam penelitian ini adalah antara 0,7736 oleh RHB Alpha Sector Rotation sampai yang paling rendah sebesar 0,3350 oleh saham MNC Dana Ekuitas. Semakin besar hasil indeks Sharpe yang dicapai, maka semakin baik pula kinerja portofolio saham karena menghasilkan return yang lebih tinggi atas risiko individual yang ditanggungnya. 
2. Perhitungan Reksa Dana Saham Konvensional Tahun 2015 dengan Metode Sharpe

\begin{tabular}{|l|l|c|}
\hline No. & \multicolumn{1}{|c|}{$\begin{array}{c}\text { Reksa Dana Saham } \\
\text { Konvensional }\end{array}$} & Sharpe \\
\hline 1. & BNP Paribas Ekuitas & $-0,2762$ \\
\hline 2. & MNC Dana Ekuitas & $-0,2751$ \\
\hline 3. & Manulife Saham Andalan & $-0,3784$ \\
\hline 4. & $\begin{array}{l}\text { RHB Alpha Sector } \\
\text { Rotation }\end{array}$ & $-0,2149$ \\
\hline 5. & Simas Saham Unggulan & $-0,4096$ \\
\hline 6. & TRIM Kapital & $-0,3179$ \\
\hline 7. & $\begin{array}{l}\text { CIMB Principal Total } \\
\text { Return Equity Fund }\end{array}$ & $-0,4063$ \\
\hline
\end{tabular}

Berdasarkan tabel hasil perhitungan kinerja di atas, terdapat 7 reksadana saham syariah yang menghasilkan kinerja negatif. Hal ini menunjukkan bahwa 7 reksa dana saham konvensional tersebut kurang layak dijadikan sebagai tempat investasi. Kisaran nilai indeks Sharpe dalam penelitian ini adalah antara -0,2149 oleh RHB Alpha Sector Rotation sampai yang paling rendah sebesar -0,4096 oleh saham Simas Saham Unggulan. Semakin kecil hasil indeks Sharpe yang dicapai, maka semakin buruk pula kinerja portofolio saham karena menghasilkan pengembalian yang lebih tinggi atas risiko individual yang ditanggungnya.

3. Perhitungan Reksa Dana Saham Konvensional Tahun 2016 dengan Metode Sharpe

\begin{tabular}{|l|l|c|}
\hline No. & \multicolumn{1}{|c|}{$\begin{array}{c}\text { Reksa Dana Saham } \\
\text { Konvensional }\end{array}$} & Sharpe \\
\hline 1. & BNP Paribas Ekuitas & 0,0279 \\
\hline 2. & MNC Dana Ekuitas & 0,2760 \\
\hline 3. & Manulife Saham Andalan & 0,1976 \\
\hline 4. & $\begin{array}{l}\text { RHB Alpha Sector } \\
\text { Rotation }\end{array}$ & 0,1553 \\
\hline 5. & Simas Saham Unggulan & 0,2343 \\
\hline 6. & TRIM Kapital Principal Total & $-0,0551$ \\
\hline 7. & $\begin{array}{l}\text { CIMB Peturn Equity Fund } \\
\text { Return }\end{array}$ \\
\hline
\end{tabular}

Berdasarkan tabel hasil perhitungan kinerja di atas, terdapat 6 reksadana saham konvensional yang menghasilkan kinerja positif dan 1 reksa dana saham konvensional yang menghasilkan kinerja negatif. Hal ini menunjukkan bahwa 6 reksa dana saham konvensional tersebut layak dijadikan sebagai tempat investasi, yaitu BNP Paribas Ekuitas, MNC Dana Ekuitas, Manulife Saham Andalan, RHB Alpha Sector Rotation, Simas Saham Unggulan, dan CIMB Principal Total Return Equity Fund. Kisaran nilai indeks Sharpe dalam penelitian ini adalah antara 0,2760 oleh MNC Dana Ekuitas sampai yang paling rendah sebesar 0,0551 oleh saham TRIM Kapital.

\section{Perhitungan Reksa Dana Saham Konvensional Tahun 2017 dengan Metode Sharpe}




\begin{tabular}{|l|l|c|}
\hline No. & \multicolumn{1}{|c|}{$\begin{array}{c}\text { Reksa Dana Saham } \\
\text { Konvensional }\end{array}$} & Sharpe \\
\hline 1. & BNP Paribas Ekuitas & 0,4437 \\
\hline 2. & MNC Dana Ekuitas & 0,0500 \\
\hline 3. & Manulife Saham Andalan & 0,1849 \\
\hline 4. & $\begin{array}{l}\text { RHB Alpha Sector } \\
\text { Rotation }\end{array}$ & 0,4217 \\
\hline 5. & Simas Saham Unggulan & 0,1876 \\
\hline 6. & TRIM Kapital Principal Total & 0,4942 \\
\hline 7. & $\begin{array}{l}\text { CIMB Prity Fund } \\
\text { Return Equity Fif }\end{array}$ \\
\hline
\end{tabular}

Berdasarkan tabel hasil perhitungan kinerja di atas, terdapat 7 reksadana saham konvensional yang menghasilkan kinerja positif. Kinerja reksa dana saham konvensional dengan hasil positif menunjukkan bahwa return yang diperoleh lebih besar dari return investasi bebas risiko. Kisaran nilai indeks Sharpe dalam penelitian ini adalah antara 0,6159 oleh CIMB Principal Total Return Equity Fund sampai yang paling rendah sebesar 0,0500 oleh saham MNC Dana Ekuitas.

\section{Perhitungan Reksa Dana Saham Konvensional Tahun 2018 dengan} Metode Sharpe

\begin{tabular}{|l|l|c|}
\hline No. & \multicolumn{1}{|c|}{$\begin{array}{c}\text { Reksa Dana Saham } \\
\text { Konvensional }\end{array}$} & Sharpe \\
\hline 1. & BNP Paribas Ekuitas & 0,3293 \\
\hline 2. & MNC Dana Ekuitas & 0,1468 \\
\hline 3. & Manulife Saham Andalan & 0,2176 \\
\hline 4. & $\begin{array}{l}\text { RHB Alpha Sector } \\
\text { Rotation }\end{array}$ & 0,2678 \\
\hline 5. & Simas Saham Unggulan & 0,0126 \\
\hline 6. & TRIM Kapital & 0,1421 \\
\hline 7. & $\begin{array}{l}\text { CIMB Principal Total } \\
\text { Return Equity Fund }\end{array}$ & 0,4204 \\
\hline
\end{tabular}

Berdasarkan tabel hasil perhitungan kinerja di atas, terdapat 7 reksadana saham konvensional yang menghasilkan kinerja positif. Hal ini menunjukkan bahwa 7 reksadana saham konvensional tersebut layak dijadikan sebagai tempat investasi. Kisaran nilai indeks Sharpe dalam penelitian ini adalah antara 0,4204 oleh CIMB Principal Total Return Equity Fund sampai yang paling rendah sebesar 0,0126 oleh saham Simas Saham Unggulan.

\section{B. Kinerja Reksa Dana Saham Konvensional dengan Metode Treynor Tahun} $2014-2018$

1. Perhitungan Reksa Dana Saham Konvensional Tahun 2014 dengan Metode Treynor

\begin{tabular}{|l|l|c|}
\hline No. & \multicolumn{1}{|c|}{$\begin{array}{c}\text { Reksa Dana Saham } \\
\text { Konvensional }\end{array}$} & Treynor \\
\hline 1. & BNP Paribas Ekuitas & 0,0127 \\
\hline 2. & MNC Dana Ekuitas & 0,0081 \\
\hline
\end{tabular}




\begin{tabular}{|l|l|c|}
\hline 3. & Manulife Saham Andalan & 0,0109 \\
\hline 4. & $\begin{array}{l}\text { RHB Alpha Sector } \\
\text { Rotation }\end{array}$ & 0,0153 \\
\hline 5. & Simas Saham Unggulan & 0,0342 \\
\hline 6. & TRIM Kapital Principal Total & 0,0172 \\
\hline 7. & $\begin{array}{l}\text { CIMB Pert45 } \\
\text { Return Equity Fund }\end{array}$ \\
\hline
\end{tabular}

Berdasarkan tabel hasil perhitungan kinerja di atas, terdapat 7 reksadana saham konvensional yang menghasilkan kinerja positif. Hal ini menunjukkan bahwa 7 reksa dana saham konvensional layak dijadikan sebagai tempat investasi. Kisaran nilai indeks Treynor dalam penelitian ini adalah antara 0,0342 oleh Simas Saham Unggulan sampai yang paling rendah sebesar 0,0081 oleh saham MNC Dana Ekuitas. Semakin besar hasil indeks Sharpe yang dicapai, maka semakin baik pula kinerja portofolio saham karena menghasilkan return yang lebih tinggi atas risiko individual yang ditanggungnya.

2. Perhitungan Reksa Dana Saham Konvensional Tahun 2015 dengan Metode Treynor

\begin{tabular}{|l|l|c|}
\hline No. & \multicolumn{1}{|c|}{$\begin{array}{c}\text { Reksa Dana Saham } \\
\text { Konvensional }\end{array}$} & Treynor \\
\hline 1. & BNP Paribas Ekuitas & $-0,0127$ \\
\hline 2. & MNC Dana Ekuitas & $-0,0142$ \\
\hline 3. & Manulife Saham Andalan & $-0,0175$ \\
\hline 4. & $\begin{array}{l}\text { RHB Alpha Sector } \\
\text { Rotation }\end{array}$ & $-0,0134$ \\
\hline 5. & Simas Saham Unggulan & $-0,0225$ \\
\hline 6. & TRIM Kapital & $-0,0150$ \\
\hline 7. & $\begin{array}{l}\text { CIMB Principal Total } \\
\text { Return Equity Fund }\end{array}$ & $-0,0194$ \\
\hline
\end{tabular}

Berdasarkan tabel hasil perhitungan kinerja reksadana di atas, terdapat 7 sampel penelitian yang semuanya menghasilkan kinerja negatif. Kisaran nilai indeks Treynor dalam penelitian ini adalah antara -0,0127 oleh BNP Paribas Ekuitas sampai yang paling rendah sebesar -0,0225 oleh saham Simas Saham Unggulan. Semakin kecil hasil indeks Sharpe yang dicapai, maka semakin buruk pula kinerja portofolio saham karena menghasilkan pengembalian yang lebih tinggi atas risiko individual yang ditanggungnya.

\section{Perhitungan Reksa Dana Saham Konvensional Tahun 2016 dengan} Metode Treynor

\begin{tabular}{|l|l|c|}
\hline No. & \multicolumn{1}{|c|}{$\begin{array}{c}\text { Reksa Dana Saham } \\
\text { Konvensional }\end{array}$} & Treynor \\
\hline 1. & BNP Paribas Ekuitas & 0,0008 \\
\hline 2. & MNC Dana Ekuitas & 0,0082 \\
\hline 3. & Manulife Saham Andalan & 0,0058 \\
\hline 4. & $\begin{array}{l}\text { RHB Alpha Sector } \\
\text { Rotation }\end{array}$ & 0,0045 \\
\hline
\end{tabular}




\begin{tabular}{|c|c|c|}
\hline 5. & Simas Saham Unggulan & 0,0104 \\
\hline 6. & TRIM Kapital & $-0,0017$ \\
\hline 7. & $\begin{array}{lll}\text { CIMB Principal } & \text { Total } \\
\text { Return Equity Fund } & \end{array}$ & 0,0068 \\
\hline
\end{tabular}

Berdasarkan tabel hasil perhitungan kinerja di atas, terdapat 6 reksadana saham konvensional yang menghasilkan kinerja positif dan terdapat 1 reksadana saham konvensional yang menghasilkan kinerja negatif. Hal ini menunjukkan bahwa 6 reksa dana saham konvensional tersebut layak dijadikan sebagai tempat investasi. Kisaran nilai indeks Treynor dalam penelitian ini adalah antara 0,0104 oleh Simas Saham Unggulan sampai yang paling rendah sebesar -0,0017 oleh Trim Kapital.

4. Perhitungan Reksa Dana Saham Konvensional Tahun 2017 dengan Metode Treynor

\begin{tabular}{|l|l|c|}
\hline No. & \multicolumn{1}{|c|}{$\begin{array}{c}\text { Reksa Dana Saham } \\
\text { Konvensional }\end{array}$} & Treynor \\
\hline 1. & BNP Paribas Ekuitas & 0,0092 \\
\hline 2. & MNC Dana Ekuitas & 0,0017 \\
\hline 3. & Manulife Saham Andalan & 0,0044 \\
\hline 4. & $\begin{array}{l}\text { RHB Alpha Sector } \\
\text { Rotation }\end{array}$ & 0,0093 \\
\hline 5. & Simas Saham Unggulan & 0,0109 \\
\hline 6. & TRIM Kapital Principal Total & 0,0124 \\
\hline 7. & $\begin{array}{l}\text { CIMB Prity Fund } \\
\text { Return Equity Fe149 }\end{array}$ \\
\hline
\end{tabular}

Berdasarkan tabel hasil perhitungan kinerja di atas, terdapat 7 reksadana saham konvensional yang menghasilkan kinerja positif. Hal ini menunjukkan bahwa 7 reksa dana saham konvensional tersebut layak dijadikan sebagai tempat investasi. Kinerja reksa dana saham konvensional dengan hasil positif menunjukkan bahwa return yang diperoleh lebih besar dari return investasi bebas risiko. Kisaran nilai indeks Treynor dalam penelitian ini adalah antara 0,0149 oleh CIMB Principal Total Return Equity Fund sampai yang paling rendah sebesar 0,0017 oleh saham MNC Dana Ekuitas.

5. Perhitungan Reksa Dana Saham Konvensional Tahun 2018 dengan Metode Treynor

\begin{tabular}{|l|l|c|}
\hline No. & \multicolumn{1}{|c|}{$\begin{array}{c}\text { Reksa Dana Saham } \\
\text { Konvensional }\end{array}$} & Treynor \\
\hline 1. & BNP Paribas Ekuitas & 0,8091 \\
\hline 2. & MNC Dana Ekuitas & 0,8793 \\
\hline 3. & Manulife Saham Andalan & 0,5926 \\
\hline 4. & $\begin{array}{l}\text { RHB Alpha Sector } \\
\text { Rotation }\end{array}$ & 0.3811 \\
\hline 5. & Simas Saham Unggulan & 0.1655 \\
\hline 6. & TRIM Kapital Principal Total & 0,6076 \\
\hline 7. & $\begin{array}{l}\text { CIMB Priturn Equity Fund } \\
\text { Return }\end{array}$ \\
\hline
\end{tabular}


Berdasarkan tabel hasil perhitungan kinerja di atas, terdapat 7 reksadana saham konvensional yang menghasilkan kinerja positif. Hal ini menunjukkan bahwa 7 reksa dana saham konvensional tersebut layak dijadikan sebagai tempat investasi. Kisaran nilai indeks Treynor dalam penelitian ini adalah antara 0,8793 oleh MNC Dana Ekuitas sampai yang paling rendah sebesar 0,1655 oleh saham Simas Saham Unggulan. Semakin besar hasil indeks Treynor yang dicapai, maka semakin baik pula kinerja portofolio saham karena menghasilkan pengembalian yang lebih tinggi atas risiko individual yang ditanggungnya.

\section{Kinerja Reksa Dana Saham Konvensional dengan Metode Jensen Tahun $2014-2018$}

1. Perhitungan Reksa Dana Saham Konvensional Tahun 2014 dengan Metode Jensen

\begin{tabular}{|l|l|c|}
\hline No. & \multicolumn{1}{|c|}{$\begin{array}{c}\text { Reksa Dana Saham } \\
\text { Konvensional }\end{array}$} & Jensen \\
\hline 1. & BNP Paribas Ekuitas & 0,0022 \\
\hline 2. & MNC Dana Ekuitas & $-0,0020$ \\
\hline 3. & Manulife Saham Andalan & 0,0001 \\
\hline 4. & $\begin{array}{l}\text { RHB Alpha Sector } \\
\text { Rotation }\end{array}$ & 0,0065 \\
\hline 5. & Simas Saham Unggulan & 0,0176 \\
\hline 6. & TRIM Kapital Principal Total & 0,0065 \\
\hline 7. & $\begin{array}{l}\text { CIMB Prity Fund } \\
\text { Return Equity Fund }\end{array}$ \\
\hline
\end{tabular}

Berdasarkan tabel hasil perhitungan kinerja di atas, terdapat 6 reksadana saham konvensional yang menghasilkan kinerja positif dan terdapat 1 reksadana saham konvensional yang menghasilkan kinerja negatif. Hal ini menunjukkan bahwa 6 reksa dana saham konvensional tersebut layak dijadikan sebagai tempat investasi, yaitu BNP Paribas Ekuitas, MNC Dana Ekuitas, Manulife Saham Andalan, RHB Alpha Sector Rotation, Simas Saham Unggulan, CIMB Principal Total Return Equity Fund. Kisaran nilai indeks Jensen dalam penelitian ini adalah antara 0,0176 oleh Simas Saham Unggulan sampai yang paling rendah sebesar 0,0020 oleh MNC Dana Ekuitas.

2. Perhitungan Reksa Dana Saham Konvensional Tahun 2015 dengan Metode Jensen

\begin{tabular}{|l|l|c|}
\hline No. & \multicolumn{1}{|c|}{$\begin{array}{c}\text { Reksa Dana Saham } \\
\text { Konvensional }\end{array}$} & Jensen \\
\hline 1. & BNP Paribas Ekuitas & 0,0038 \\
\hline 2. & MNC Dana Ekuitas & 0,0017 \\
\hline 3. & Manulife Saham Andalan & $-0,0017$ \\
\hline 4. & $\begin{array}{l}\text { RHB Alpha Sector } \\
\text { Rotation }\end{array}$ & 0,0029 \\
\hline 5. & Simas Saham Unggulan & $-0,0060$ \\
\hline 6. & TRIM Kapital & 0,0012 \\
\hline 7. & $\begin{array}{l}\text { CIMB Principal Total } \\
\text { Return Equity Fund }\end{array}$ & $-0,0041$ \\
\hline
\end{tabular}


Berdasarkan tabel hasil perhitungan kinerja di atas, terdapat 4 reksadana saham konvensional yang menghasilkan kinerja positif dan terdapat 3 reksadana saham konvensional yang menghasilkan kinerja negatif. Hal ini menunjukkan bahwa 4 reksa dana saham konvensional berdasarkan metode Jensen tersebut layak dijadikan sebagai tempat investasi, yaitu BNP Paribas Ekuitas, MNC Dana Ekuitas, RHB Alpha Sector Rotation, dan Trim Kapital. Kisaran nilai indeks Jensen dalam penelitian ini adalah antara 0,0038 oleh BNP Paribas Ekuitas sampai yang paling rendah sebesar -0,0060 oleh Simas Saham Unggulan.

\section{Perhitungan Reksa Dana Saham Konvensional Tahun 2016 dengan Metode Jensen}

\begin{tabular}{|l|l|c|}
\hline No. & \multicolumn{1}{|c|}{$\begin{array}{c}\text { Reksa Dana Saham } \\
\text { Konvensional }\end{array}$} & Jensen \\
\hline 1. & BNP Paribas Ekuitas & $-0,0074$ \\
\hline 2. & MNC Dana Ekuitas & 0,0012 \\
\hline 3. & Manulife Saham Andalan & $-0,0018$ \\
\hline 4. & $\begin{array}{l}\text { RHB Alpha Sector } \\
\text { Rotation }\end{array}$ & $-0,0033$ \\
\hline 5. & Simas Saham Unggulan & 0,0022 \\
\hline 6. & TRIM Kapital Principal Total & $-0,0080$ \\
\hline 7. & $\begin{array}{l}\text { CIMB Peturn Equity Fund } \\
\text { Retur }\end{array}$ \\
\hline
\end{tabular}

Berdasarkan tabel hasil perhitungan kinerja di atas, terdapat 2 reksadana saham konvensional yang menghasilkan kinerja positif dan terdapat 5 reksadana saham konvensional yang menghasilkan kinerja negatif. Hal ini menunjukkan bahwa 2 reksadana saham konvensional tersebut layak dijadikan sebagai tempat investasi, yaitu MNC Dana Ekuitas, Simas Saham Unggulan. Kisaran nilai indeks Jensen dalam penelitian ini adalah antara 0,0022 oleh Simas Saham Unggulan sampai yang paling rendah sebesar -0,0080 oleh Trim Kapital.

\section{Perhitungan Reksa Dana Saham Konvensional Tahun 2017 dengan} Metode Jensen

\begin{tabular}{|l|l|c|}
\hline No. & \multicolumn{1}{|c|}{$\begin{array}{c}\text { Reksa Dana Saham } \\
\text { Konvensional }\end{array}$} & Jensen \\
\hline 1. & BNP Paribas Ekuitas & $-0,0025$ \\
\hline 2. & MNC Dana Ekuitas & $-0,0054$ \\
\hline 3. & Manulife Saham Andalan & $-0,0052$ \\
\hline 4. & $\begin{array}{l}\text { RHB Alpha Sector } \\
\text { Rotation }\end{array}$ & $-0,0024$ \\
\hline 5. & Simas Saham Unggulan & $-0,0003$ \\
\hline 6. & TRIM Kapital Principal Total & 0,0005 \\
\hline 7. & $\begin{array}{l}\text { CIMB Peturn Equity Fund } \\
\text { Retur }\end{array}$ \\
\hline
\end{tabular}

Berdasarkan tabel hasil perhitungan kinerja di atas, terdapat 2 reksadana saham konvensional yang menghasilkan kinerja positif dan terdapat 5 reksadana saham konvensional yang menghasilkan kinerja negatif. Hal ini menunjukkan bahwa 2 reksa dana saham konvensional tersebut layak dijadikan sebagai tempat investasi, yaitu TRIM Kapital, CIMB Principal Total Return Equity Fund. Kisaran 
nilai indeks Jensen dalam penelitian ini adalah antara 0,0021 oleh CIMB Principal Total Return Equity Fund sampai yang paling rendah sebesar -0,0054 oleh MNC Dana Ekuitas.

\section{Perhitungan Reksa Dana Saham Konvensional Tahun 2018 dengan} Metode Jensen

\begin{tabular}{|l|l|c|}
\hline No. & \multicolumn{1}{|c|}{$\begin{array}{c}\text { Reksa Dana Saham } \\
\text { Konvensional }\end{array}$} & Jensen \\
\hline 1. & BNP Paribas Ekuitas & $-0,0262$ \\
\hline 2. & MNC Dana Ekuitas & $-0,0311$ \\
\hline 3. & Manulife Saham Andalan & $-0,0316$ \\
\hline 4. & $\begin{array}{l}\text { RHB Alpha Sector } \\
\text { Rotation }\end{array}$ & $-0,0294$ \\
\hline 5. & Simas Saham Unggulan & $-0,0319$ \\
\hline 6. & TRIM Kapital Principal Total & $-0,0313$ \\
\hline 7. & $\begin{array}{l}\text { CIMB Prity Fund } \\
\text { Return Equity }\end{array}$ \\
\hline
\end{tabular}

Berdasarkan tabel hasil perhitungan kinerja di atas, terdapat 7 reksadana saham konvensional yang menghasilkan kinerja negatif. Hal ini menunjukkan bahwa 7 reksa dana saham konvensional tersebut kurang layak dijadikan sebagai tempat investasi. Kinerja reksa dana saham konvensional dengan hasil negatif menunjukkan bahwa return yang diperoleh lebih kecil dari return investasi bebas risiko. Kisaran nilai indeks Jensen dalam penelitian ini adalah antara -0.0336 oleh CIMB Principal Total Return Equity Fund sampai yang paling rendah sebesar 0,0262 oleh BNP Paribas Ekuitas.

\section{SIMPULAN}

1. Berdasarkan hasil perhitungan metode Sharpe pada tahun 2014 dan 2015 kinerja reksadana saham konvensional lebih baik dibandingkan kinerja reksadana syariah, walaupun mengalami penurunan kinerja. Di tahun 2016 reksadana saham syariah menunjukkan kinerja yang lebih baik dibandingkan dengan reksadana saham konvensional. Namun untuk tahun 2017 dan 2018 reksadana saham konvensional lebih baik dibandingkan reksadana saham konvensional.

2. Berdasarkan hasil perhitungan metode Treynor pada tahun 2014 dan 2015 kinerja reksadana saham konvensional lebih baik dibandingkan kinerja reksadana syariah, walaupun mengalami penurunan kinerja. Di tahun 2016 reksadana saham syariah menunjukkan kinerja yang lebih baik dibandingkan dengan reksadana saham konvensional. Namun untuk tahun 2017 dan 2018 reksadana saham konvensional lebih baik dibandingkan reksadana saham syariah.

3. Berdasarkan hasil perhitungan metode Jensen pada tahun 2014, 2015, 2016 dan 2018 kinerja reksadana saham syariah lebih baik dibandingkan dengan kinerja reksadana saham konvensional. Pada tahun 2017 kinerja reksadana saham syariah sama dengan kinerja reksadana saham konvensional. 


\section{DAFTAR PUSTAKA}

Bakhri, Syaeful. (2018). Minat Mahasiswa Dalam Investasi di Pasar Modal. Jurnal Al Amwal, 10 (1).

Bursa Efek Indonesia. (2018). Reksa Dana. Diakses dari https://www.idx.co.id/ (18 Maret 2020).

Putri, Diah Tri Handayani dan Worokinasih, Saparila. (2018). Analisis Kinerja Investasi Reksa Dana Syariah di Indonesia dengan Metode Sharpe, Treynor dan Jensen (Studi Pada Reksa Dana Saham Syariah yang Terdaftar di Otoritas Jasa Keuangan Periode 2015-2017). Jurnal Administrasi Bisnis. 59 (1).

Huda, Nurul., et al. (2017). Analisis Perbandingan Kinerja Reksa Dana Saham Syariah dan Konvensional Periode 2012-2015. Itishadia: Jurnal Kajian Ekonomi dan Bisnis Islam, 10 (2).

Lailiyah, E. H., dan Sulasmiyati, S. (2016). Analisis Perbandingan Kinerja Reksadana Syariah dan Reksadana Konvensional (Studi pada Reksadana yang Terdaftar di Otoritas Jasa Keuangan Periode 2012 2016. Jurnal Administrasi Bisnis (JAB), 35 (2).

Lorencia, Maria dan Taufiq, M. (2020). Analisis Komparatif Kinerja Reksadana Saham dan Reksadana Indeks Berdasarkan Metode Sharpe,

Treynor, dan Jensen. Jurnal Dinamika Ekonomi Pembangunan (JDEP), 3 (1).

Nasution, Mustafa Edwin dan Huda, Nurul. (2014). Investasi pada Pasar Modal Syariah, Edisi Revisi, cetakan ke 3. Jakarta: Kencana.

OJK. (2015). Peraturan Otoritas Jasa Keuangan Nomor 19/POJK.04/2015 Tentang Penerbitan dan Persyaratan Reksa Dana Syariah. Diakses dari https://www.ojk.go.id/id/. (17 Maret 2020).

Putra, Jepryansyah dan Fauzie, Syarief. (2014). Analisis Perbandingan Kinerja Reksa Dana Konvensional dengan Reksa Dana Syariah di Indonesia. Jurnal Ekonomi dan Keuangan, 2 (5).

Rahmah, Azizatur. (2016). Analisis Perbandingan Kinerja Reksa Dana Syariah dan Kinerja Reksa Dana Konvensional dengan Metode Sharpe, Treynor dan Jensen. Analytica Islamica Journal, 5 (1).

Simatupang, Mangsa. (2010). Pengetahuan Praktis Investasi Saham dan Reksadana, Jakarta: Mitra Wacana Media.

Zamzany, F.R., dan Setiawan, E. (2018). Studi Komparatif Kinerja Reksadana Saham Konvensional dan Syariah Di Indonesia. Akuntabilitas: Jurnal Ilmu Akuntansi, 11 (2). 